INKLUSIF Vol 3. No. 2 Desember 2018

\title{
FAKTOR - FAKTOR YANG MEMPENGARUHI PENGHIMPUNAN DEPOSITO MUDHARABAH PADA BANK PEMBIAYAAN RAKYAT SYARI'AH (BPRS) DI INDONESIA PERIODE 2012-2014
}

\author{
Ai Fitri Islami ${ }^{1}$ \\ Email : fitriislami16@gmail.com
}

\begin{abstract}
The purpose of this study was to determine the long-term balance and influence of institutional and macroeconomic variables on the collection of mudharabah deposits Syari'ah People's Financing Bank (BPRS) in Indonesia for the period 2012 to 2014.

The results of this study are that there is a long-term balance of institutional and macro variables economy towards the collection of BPRS mudharabah deposits in Indonesia. Institutional variables that have a significant partial effect on mudharabah deposit collection Macroeconomic variables that have a significant partial effect on the collection of mudharabah deposits. Institutional and macroeconomic variables simultaneously have a significant effect on the collection of mudharabah deposits. In the short term, the profit sharing ratio coefficient is greater than the BI Rate, so it can be concluded that the variable profit sharing ratio is more influential than the BI Rate. In the long run, the BI Rate variable is more influential than the profit sharing ratio.
\end{abstract}

Keywords: Mudharabah deposits, GDP, BI Rate, Inflation, Profit Sharing Ratio.

\section{ABSTRAK}

Tujuan penelitian ini adalah untuk mengetahui keseimbangan jangka panjang dan pengaruh variabel kelembagaan dan makro ekonomi terhadap penghimpunan deposito mudharabah Bank Pembiayaan Rakyat Syari'ah (BPRS) di Indonesia periode 2012 s.d. 2014.

Hasil dari penelitian menunjukkan keseimbangan jangka panjang variabel kelembagaan dan makro ekonomi terhadap penghimpunan deposito mudharabah BPRS di Indonesia. Variabel kelembagaan yang berpengaruh nyata secara parsial terhadap penghimpunan deposito mudharabah Variabel makro ekonomi yang berpengaruh nyata secara parsial terhadap penghimpunan deposito mudharabah. Variabel kelembagaan dan makro ekonomi secara serempak berpengaruh nyata terhadap penghimpunan deposito mudharabah. Dalam jangka pendek koefisien nisbah bagi hasil lebih besar dari pada BI Rate, sehingga dapat disimpulkan bahwa variabel nisbah bagi hasil lebih berpengaruh daripada BI Rate. Dalam jangka panjang variabel BI Rate lebih berpengaruh daripada nisbah bagi hasil.

Kata kunci: Deposito mudharabah, GDP, BI Rate, Inflasi, Nisbah Bagi Hasil.

\footnotetext{
${ }^{1}$ Mahasiswa Pascasarjana IAIN Syekh Nurjati Cirebon.
} 
INKLUSIF Vol 3. No. 2 Desember 2018

\section{PENDAHULUAN}

\section{A. Latar Belakang}

Deregulasi finansial di Indonesia telah memberikan iklim bagi tumbuh kembangnya Bank Syari'ah di Indonesia. Pada tahun 1991 berdiri dua Bank Syari'ah, yaitu BPR Syari'ah Dana Mardhotillah, BPR Syari'ah Berkah Amal Sejahtera yang keduanya berada di Bandung. Pada tahun 1992 terdapat UU Perbankan No 7 tahun 1992 yang isinya tentang bagi hasil bagi pihak perbankan. Saat itu berdiri Bank Muamalat Indonesia, yang kemudian diikuti oleh BPR Syari'ah Bangun Drajad Warga dan BPR Syari'ah Margi Rizki Bahagia di Yogyakarta. ${ }^{2}$

Reaksi berikutnya juga muncul, untuk melakukan revisi UU No 7 tahun 1992 menjadi UU No 10 tahun 1998. Dengan diterbitkannya UU No 10 tahun 1998 muncul hikmah tersendiri bagi dunia perbankan nasional dimana pemerintah membuka lebar kegiatan usaha perbankan dengan berdasarkan prinsip syari'ah. Setelah UU No 10 tahun 1998 di Indonesia telah berdiri Bank Muamalat Indonesia ditambah dengan 80 BPR Syari'ah.

Jika dilihat secara makroekonomi, pengembangan Bank Syari'ah di Indonesia memiliiki peluang besar karena peluang pasarnya yang luas sejurus dengan mayoritas penduduk indonesia yang beragama Islam. UU No 10 tidak menutup kemungkinan bagi pemilik bank negara, swasta nasional bahkan pihak asing sekalipun untuk membuka cabang syari'ahnya di Indonesia. Dengan terbukanya kesempatan ini jelas akan memperluas peluang transaksi keuangan di dunia perbankan, terutama apabila terjalin hubungan kerjasama diantara BankBank Syari'ah. ${ }^{3}$

Pada publikasi Bank Indonesia dalam Laporan Perkembangan Perbankan Syari'ah, ${ }^{4}$ kinerja perekonomian Indonesia pada tahun 2012 cukup menggembirakan di tengah perekonomian dunia yang melemah dan diliputi ketidakpastian. Pertumbuhan ekonomi dapat dipertahankan pada tingkat yang cukup tinggi, yaitu 6,2\%, dengan inflasi yang terkendali pada tingkat yang rendah (4,3\%) sehingga berada pada kisaran sasaran inflasi 4,5\%. Di tengah menurunnya kinerja ekspor, pertumbuhan ekonomi lebih banyak ditopang oleh permintaan domestik yang tetap kuat, terutama yang berasal dari konsumsi rumah tangga yang mencapai pertumbuhan tertinggi sejak krisis keuangan global tahun 2008/2009, didukung oleh terjaganya daya beli dan keyakinan konsumen yang meningkat.

Selain itu secara sektoral, pertumbuhan ekonomi domestik masih ditopang oleh tiga sektor utama, yaitu sektor industri pengolahan, sektor perdagangan, hotel dan restoran (PHR), serta sektor pengangkutan dan komunikasi. Perkembangan tersebut didukung oleh kondisi ekonomi makro dan sistem keuangan yang kondusif yang memungkinkan rumah tangga dan sektor usaha melakukan kegiatan ekonominya dengan baik. Kondusifnya kondisi makro dan sistem keuangan dimaksud tidak terlepas dari bauran kebijakan moneter, nilai tukar dan makroprudensial serta penguatan koordinasi dengan pemerintah yang ditempuh Bank Indonesia.

\footnotetext{
2 Otoritas Jasa Keuangan, “Laporan Perkembangan Perbankan Syari'ah Bank Indonesia” (Jakarta: Departemen Perbankan Syari'ah, 2012).1.

${ }^{3}$ Muhammad, Manajemen Bisnis, 2005th ed., vol. 3 (Yogyakarta: UPP AMP YKPN, 2015).18.

${ }^{4}$ Departemen Perbankan Syari'ah, “Laporan Perkembangan Perbankan Syari'ah” (Jakarta: Bank Indonesia, 2012 ).1.
} 
Kondisi perekonomian yang kondusif juga berdampak positif terhadap perkembangan Perbankan Syariah. Secara nasional, volume usaha Perbankan Syariah yang terdiri atas Bank Umum Syariah (BUS), Unit Usaha Syariah (UUS) dan Bank Pembiayaan Rakyat Syariah (BPRS) meningkat 34,0\% (yoy) dari posisi Rp 149,0 Triliun pada tahun 2011, menjadi Rp 199,7 Triliun pada tahun 2012. Laju pertumbuhan volume usaha tersebut lebih rendah dibandingkan tahun lalu $(48,6 \%$, yoy) dan terutama dialami oleh kelompok BUS. Laju pertumbuhan aset Perbankan Syariah lebih tinggi dibandingkan pertumbuhan aset perbankan secara nasional, sehingga pangsa pasar Perbankan Syariah terhadap Industri Perbankan Nasional meningkat dari 4,0\% menjadi 4,6\%. Pertumbuhan aset diikuti pelaksanaan intermediasi dana pihak ketiga yang dihimpun yang mencapai Rp 150,5 Triliun, pada berbagai segmen pembiayaan secara optimal. ${ }^{5}$

\section{Gambar Perkembangan Asset Bank Syari'ah}

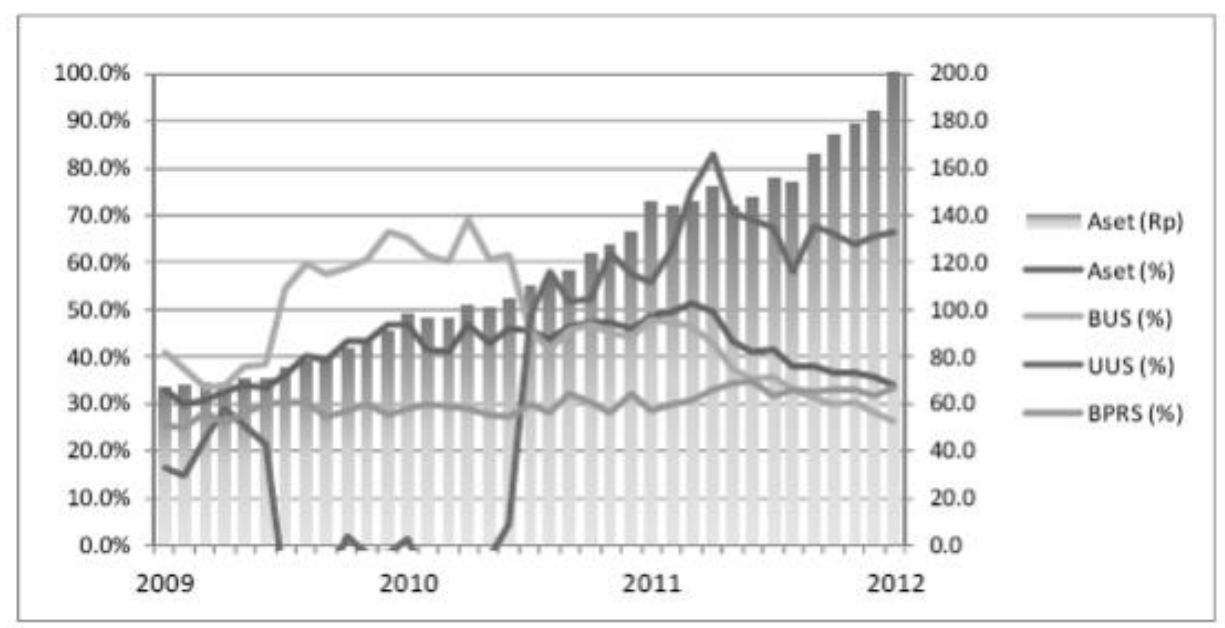

Jumlah bank yang melakukan kegiatan usaha berdasarkan prinsip syariah pada tahun 2012 bertambah seiring dengan beroperasinya sejumlah bank syariah baru. Jumlah BPRS bertambah dari 155 BPRS menjadi 158 BPRS. Penambahan jumlah BPRS tersebut bersumber dari 3 izin pendirian usaha baru dan 1 izin konversi dari BPR konvensional. Selain itu pada tahun 2012 juga terjadi pencabutan izin usaha 1 BPRS. Wilayah lokasi usaha 155 BPRS tersebut tersebar pada 22 propinsi di Indonesia, dengan jumlah terbanyak terdapat di Jawa Timur sebanyak 30 BPRS, diikuti Jawa Barat sebanyak 29 BPRS. Penyebaran BPRS yang belum merata dengan sebaran terbanyak berada di pulau Jawa membuka peluang bagi para investor yang ingin membuka BPRS baru terutama di 12 propinsi lainnya yang belum memiliki BPRS. Bertambahnya jumlah Bank Syariah juga diikuti dengan penambahan Jaringan Kantor Bank Syariah, yang pada periode laporan bertambah sebanyak 565 kantor. Dari jumlah itu 40 kantor lainnya merupakan jaringan kantor baru BPRS. ${ }^{6}$

\footnotetext{
${ }^{5}$ Departemen Perbankan Syari'ah.2.

${ }^{6}$ Departemen Perbankan Syari'ah. 4.
} 
INKLUSIF Vol 3. No. 2 Desember 2018

Tabel Perkembangan Jaringan Kantor Bank Syari’ah

\begin{tabular}{|c|c|c|c|}
\hline Kelompok Bank & 2010 & 2011 & 2012 \\
\hline Bank Umum Syariah & 11 & 11 & 11 \\
\hline Unit Usaha Syariah & 23 & 24 & 24 \\
\hline - Jumlah Kantor BUS dan UUS & 1477 & 1737 & 2262 \\
\hline BPRS & 150 & 155 & 158 \\
\hline - Jumlah Kantor BPRS & 286 & 364 & 401 \\
\hline
\end{tabular}

Dalam rangka proses pengembangan Perbankan Syariah, Bank Indonesia melakukan program edukasi dan promosi Perbankan Syariah kepada berbagai kalangan dalam berbagai even, baik atas inisiatif Bank Indonesia sendiri maupun bekerjasama dengan stakeholders lain. Kegiatan ini tidak hanya dilakukan di dalam negeri namun juga dilaksanakan di luar negeri seperti pelaksanaan Training of Trainers, Seminar Internasional maupun pengiriman narasumber ke luar negeri untuk lebih mengenalkan framework Pengembangan Perbankan dan Keuangan Syariah Indonesia.

Dana pihak ketiga yang dihimpun BPRS sepanjang tahun 2012 tercatat tumbuh sebesar $40,2 \%$. Berdasarkan jenis instrumen, pertumbuhan tertinggi dialami deposito (46,2\%, yoy) yang terjadi pada kelompok BPRS. Sementara pertumbuhan tabungan meningkat sebesar $27,1 \%{ }^{7}$

Tabel Perkembangan Dana Pihak Ketiga

\begin{tabular}{lrrrr} 
Kelompok Bank & Giro & Tabungan & Deposito & \multicolumn{1}{r}{ DPK } \\
Bank Umum & & & & \\
Nominal (Rp, triliun) & 17.7 & 45.1 & 84.7 & 147.5 \\
- BUS & 15.4 & 35.8 & 66.6 & 117.8 \\
- UUS & 2.3 & 9.3 & 18.1 & 29.7 \\
Pertumbuhan (yoy) & $47.5 \%$ & $38.2 \%$ & $19.7 \%$ & $27.8 \%$ \\
BPRS & & & & \\
Nominal (Rp, triliun) & - & 1.1 & 1.8 & 2.9 \\
Pertumbuhan (yoy) & - & $27.1 \%$ & $46.2 \%$ & $40.2 \%$
\end{tabular}

Berkenaan dengan prospek dan arah kebijakan perekonomian ke depan, Bank Indonesia memperkirakan pertumbuhan ekonomi Indonesia tahun 2013 relatif lebih baik dibandingkan tahun 2012 dan berkisar 6,2 - 6,6\%. Bank Indonesia juga akan terus memperkuat bauran kebijakan antara lain melalui kebijakan nilai tukar yang diarahkan untuk stabilisasi nilai tukar agar pergerakan nilai tukar rupiah tersebut sesuai dengan kondisi fundamentalnya dan kebijakan makroprudensial yang diarahkan untuk menjaga kestabilan sistem keuangan serta memperkuat

\footnotetext{
${ }^{7}$ Departemen Perbankan Syari'ah.5.
} 
INKLUSIF Vol 3. No. 2 Desember 2018

koordinasi Bank Indonesia dan Pemerintah, khususnya dalam memperkuat struktur perekonomian dan memperluas sumber pembiayaan ekonomi.

Kebijakan tersebut akan dilengkapi oleh kebijakan di bidang perbankan yang difokuskan pada tiga koridor utama yaitu pemeliharaan stabilitas sistem keuangan, penguatan ketahanan dan daya saing perbankan, dan penguatan fungsi intermediasi. Sementara untuk perbankan syariah, prospek ekonomi dan kebijakan tersebut diharapkan akan semakin mendorong pertumbuhan industri ke depan khususnya melalui potensi pasar yang masih besar yang belum tergarap sepenuhnya seiring dengan membaiknya pendapatan per kapita masyarakat, koordinasi yang lebih baik antar stakeholders dalam pengembangan keuangan syariah dan kuatnya sektor konsumsi domestik serta keberhasilan program promosi dan edukasi publik Perbankan Syariah.

Salah satu produk yang mampu mendongkrak pertumbuhan Perbankan Syari'ah di Indonesia adalah deposito dengan prinsip mudharabah. Keberadaan produk deposito mudharabah semakin kuat dengan hadirnya fatwa Majelis Ulama Indonesia melalui Dewan Syariah Nasional (DSN) mengenai deposito syariah, yaitu fatwa No: 03/DSNMUI/IV/2000. Menurut fatwa tersebut deposito yang tidak dibenarkan secara syari'ah yaitu deposito yang berdasarkan perhitungan bunga, deposito yang dibenarkan yaitu deposito yang berdasarkan prinsip mudharabah. ${ }^{8}$

Deposito mudharabah merupakan simpanan berjangka dengan akad mudharabah dimana pemilik dana (shahibul maal) mempercayakan dananya oleh bank untuk dikelola atau bertindak sebagai mudharib dengan bagi hasil sesuai dengan nisbah yang disepakati sejak awal. Jangka waktu penarikannya ada yang 1 bulan, 3 bulan, 6 bulan dan ada yang 12 bulan serta dapat diperpanjang otomatis. Secara teknis deposito mudharabah adalah akad kerjasama usaha antar dua pihak dimana nasabah bertindak sebagai shahibul maal (pemilik modal), sedangkan bank bertindak sebagai mudharib (pengelola). Keuntungan usaha dibagi menurut kesepakatan yang dituangkan dalam kontrak, sedangkan apabila rugi ditanggung oleh pemilik modal selama kerugian itu bukan akibat kelalaian pengelola. Seandainya kerugian itu diakibatkan karena kecurangan atau kelalaian pengelola, maka pengelola harus bertanggung jawab atas kerugian tersebut. ${ }^{9}$

Dengan demikian, Bank Perbiayaan Rakyat Syariah (BPRS) dalam kapasitasnya sebagai mudharib memiliki sifat sebagai seorang Wali amanah (trustee), yakni harus berhati-hati atau bijaksana serta beritikad baik dan bertanggung jawab atas segala sesuatu yang timbul akibat kesalahan atau kelalaiannya. Di samping itu, Bank Perbiayaan Rakyat Syariah (BPRS) juga bertindak sebagai kuasa dari usaha bisnis pemilik dana yang diharapkan dapat memperoleh keuntungan seoptimal mungkin tanpa melanggar berbagai aturan syariah. Dari hasil pengelolaan dana mudharabah, Bank Perbiayaan Rakyat Syariah (BPRS) membagihasilkan kepada pemilik dana sesuai dengan nisbah yang telah disepakati dan dituangkan dalam akad pembukaan rekening. 10

\footnotetext{
${ }^{8}$ Remy Sjahdeini and Sutan, Perbankan Syariah (Jakarta: Kencana Prenada Media Group, 2014). 98

${ }^{9}$ Sjahdeini and Sutan.98.

${ }^{10}$ Melayu Hasibuan, Dasar-Dasar Perbankan (jakarta: Bumi Aksara, 2009).56.
} 
Peningkatan minat masyarakat terhadap deposito mudharabah tidak terlepas dari kepuasan masyarakat terhadap bagi hasil yang diperoleh dari bank tersebut. Oleh karena itu, Bank Perbiayaan Rakyat Syariah (BPRS) perlu menganalisis seberapa besar faktor-faktor makro ekonomi maupun internal bank itu sendiri berpengaruh untuk menghasilkan jumlah penghimpunan deposito yang lebih kompetitif.

Dari uraian di atas maka peneliti ingin mengkaji apakah terdapat keseimbangan jangka panjang variabel kelembagaan dan makro ekonomi terhadap penghimpunan deposito mudharabah BPRS di Indonesia, apakah variabel kelembagaan dan makroekonomi dapat menjelaskan keadaan penghimpunan deposito mudharabah BPRS di Indonesia, seberapa besar pengaruh variabel kelembagaan dan makroekonomi secara parsial terhadap penghimpunan deposito mudharabah BPRS di Indonesia, seberapa besar pengaruh variabel kelembagaan dan makroekonomi secara serempak terhadap penghimpunan deposito mudharabah BPRS di Indonesia, Variabel kelembagaan dan makroekonomi manakah yang paling berpengaruh terhadap penghimpunan deposito mudharabah BPRS di Indonesia.

\section{B. Metode Penelitian}

Penelitian ini menggunakan metode kuantitatif dengan didukung dengan analisis statistik deskriptif. Penelitian ini merupakan studi kausal komparatif yaitu penelitian yang menunjukkan arah hubungan antara variabel bebas dengan variabel terikat, disamping mengukur kekuatan hubungannya.

Sasaran penelitian ini adalah jumlah penghimpunan deposito mudharabah BPRS, produk domestik brutto, tingkat inflasi, BI Rate, biaya promosi, jumlah karyawan, jumlah kantor. Data yang digunakan adalah data sekunder berupa data rasio dimana data yang bersifat angka dalam arti sesungguhnya (bukan kategori seperti pada data nominal dan ordinal) dan bisa dioperasikan secara matematis. ${ }^{11}$

Sebagian besar analisis ekonomi berkaitan erat dengan analisis runtun waktu yang sering diwujudkan oleh hubungan antara perubahan suatu besaran ekonomi dan kebijakan ekonomi di suatu saat serta pengaruhnya terhadap gejala dan perilaku ekonomi di saat yang lain. ${ }^{12}$

\section{PEMBAHASAN}

\section{A. Faktor - faktor yang Mempengaruhi Penghimpunan Deposito Mudharabah}

Diantara faktor-faktor yang mempengaruhi penghimpunan deposito mudharabah pada BPRS di Indonesia Periode 2012-2014 adalah Produk Domestik Brutto(PDB), tingkat inflasi, BI Rate, biaya promosi, jumlah karyawan, jumlah kantor.

Dalam lingkungan bisnis yang berubah cepat, setiap bisnis harus menang pada market yang berubah dengan cepat, marketing harus dilihat sebagai "dealing with the market" yang mengharuskan marketer dinamis dan intensif berinteraksi dengan market. Perubahan signifikan dalam lingkungan ekonomi dan kompetisi pasar, kini sebagian besar manajer menyadari bahwa

\footnotetext{
${ }^{11}$ Singgih Santoso, Mastering SPSS 18 (Jakarta: PT. Elex Media Komputindo, 2010).10.

12 Insukindro et al., Modul Ekonometrika Dasar, Yogyakarta (Yogyakarta: Bank Indonesia dan Universitas Gadjah Mada, 2004).124.
} 
untuk dapat bertahan dan tumbuh harus lebih menyadari akan dampak dari proses dan keputusan manajemen. Manajer perusahaan yang sukses cenderung berorientasi pada pemikiran strategis yang memusatkan perhatian pada pelanggan, operasi internal, pasar, dan pesaing. ${ }^{13}$

Analisis yang cermat terhadap berbagai perubahan dan usaha keberlanjutan akan memberi pemahaman yang lengkap bagi marketer yang berguna dalam menggerakkan arah bisnis dengan benar dan tepat. Analisis terhadap perubahan akan mampu melihat dengan jelas kekuatankekuatan perubahan (politik, teknologi, sosial, kultural, ekonomi, kompetitor dan konsumen) dengan analisis dari peringkat sangat penting sampai dengan peringkat yang tidak penting, yang akan berdampak secara signifikan terhadap kegiatan perusahaan. Demikian juga dengan analisis keberlanjutan untuk mengarahkan kemampuan agar setiap bisnis yang dibangun dapat bertahan hidup dalam pasar yang terus berubah dan semakin kompetitif.

Oleh karena itu, secara berkelanjutan marketer harus selalu mengadakan penyesuaian desain atau rancang bangun strategi, program, dan value untuk menggerakkan bisnis dalam mencapai sasaran. Analisis internal terhadap perusahaan akan mampu mendeteksi dan melihat ketepatan visi, budaya, dan organisasi sehingga memberi kemampuan kepada manajemen untuk mengelola aktivitas bisnis secara optimal, efisien dan efektif guna menciptakan nilai bagi stakeholder. Fungsi awal manajemen yang sangat penting dan menentukan adalah perencanaan. Dalam konteks bisnis, para pakar yakin bahwa perencanaan yang baik akan menjadi panduan dalam setiap tahapan yang seharusnya dilakukan oleh pemasar dalam memenuhi keinginan sasaran pasar. ${ }^{14}$

Analisis lingkungan didasarkan pada teori sistem, yang meliputi konsep sistem terbuka dan tertutup. Sebuah sistem atau organisasi berpola pada "energic input-output in which the energic returns from output reactivate the systems". Perilaku input-output-recycle ini berpola dan terutama berkaitan dengan saling ketergantungan pada hubungan dan struktur organisasi. Sistem tertutup, secara teoritis bersifat mandiri dan tidak membutuhkan apa-apa dari luar, gagal untuk mengenali saling ketergantungan hubungan antara lingkungan internal dan eksternal. Sistem terbuka tidak hanya mengakui bahwa lingkungan luar sangat penting untuk kelangsungan hidup, tetapi terus menerus berusaha untuk mencapai tujuan melalui kontrol atau adaptasi terhadap lingkungan eksternal. Lingkungan eksternal terdiri dari semua pemangku kepentingan organisasi, yaitu pelanggan, kreditur, masyarakat, asosiasi perdagangan, pesaing, pemasok, dan pemegang saham, serta faktor-faktor macro environmental, misalnya teknologi, sosial ekonomi, politik, dan lain-lain. Manajemen strategis meliputi penilaian berkelanjutan dari perusahaan dan lingkungannya oleh manajemen puncak. Manajemen strategis adalah proses membuat perubahan yang sesuai dalam organisasi sehingga organisasi dapat beradaptasi dengan lingkungannya dan optimal memanfaatkan peluang di pasar. ${ }^{15}$

\footnotetext{
${ }^{13}$ Loudon et al., Marketing Management: Text and Cases (New York: Best Business Books, 2005).124.

14 Adiwarman Karim, Ekonomi Makro Islami (Jakarta: PT. Raja Grafindo Persada, 2014). 3.

${ }^{15}$ Abbass F Alkhafaji, Strategic Management : Formulation, Implementation, and Control In a Dynamic Environme (New York: The Haworth Press, 2003). 60.
} 
Dalam konteks pemasaran Bank Syari'ah analisis aspek lingkungan sangat penting untuk mengetahui pengaruh yang ditimbulkannya terhadap perusahaan. Kegiatan pemasaran dipengaruhi oleh lingkungan eksternal dan internal. Dalam pengambilan keputusan untuk mencapai tujuan jangka pendek maupun jangka panjang, bagian pemasaran perlu melakukan analisis terhadap perubahan lingkungan. Lingkungan menyajikan ketidakpastian, karena sifatnya yang selalu berubah. Setiap bisnis berusaha memelihara kelangsungan hidup perusahaan, mencapai pertumbuhan, dan meningkatkan kesejahteraan, sehingga perusahaan harus melakukan penyesuaian dengan kondisi lingkungannya. ${ }^{16}$

\section{B. Hasil Penelitian}

Deskripsi data yang disajikan dari hasil penelitian ini ditampilkan dalam grafik time series yang mana bertujuan untuk mengetahui secara grafis pola pergerakan data variabel bebas berbanding variabel penghimpunan deposito mudharabah BPRS. ${ }^{17}$

\section{Grafik Time Series Variabel Deposito Mudharabah dan Produk Domestik Bruto Periode 2012 s.d 2014}

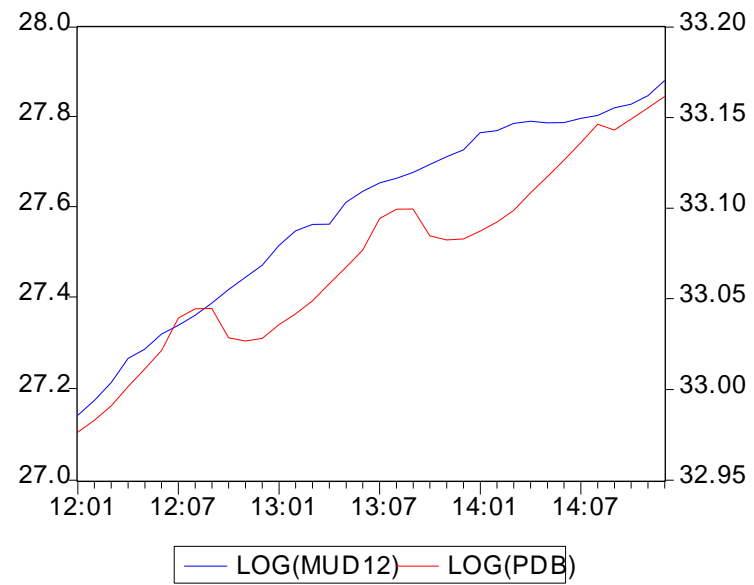

Berdasarkan grafik time series pada gambar di atas terlihat produk domestik bruto dan penghimpunan deposito mudharabah mempunyai pola pergerakan yang sama yaitu dari kiri bawah ke kanan atas dengan fluktuasi yang mirip, sehingga diduga kedua variabel ini mempunyai hubungan yang positif. Peningkatan PDB mencerminkan adanya peningkatan daya beli masyarakat yang disaat yang sama terjadi kelebihan dana yang ditanamkan pada berbagai instrumen investasi, yang salah satunya diduga pada deposito mudharabah BPRS.

\footnotetext{
${ }^{16}$ Ali Hasan, Marketing Bank Syari'ah (Bogor: Penerbit Ghalia Indonesia, 2010).13.

${ }^{17}$ Veithzal Arifin, Arvian, and A Rivai, Islamic Banking: Sebuah Teori, Konsep Dan Aplikasi (Jakarta: PT Bumi Aksara, 2010)..27.
} 
INKLUSIF Vol 3. No. 2 Desember 2018

2. Grafik Time Series Variabel Deposito Mudharabah dan Inflasi Periode 2012 s.d 2014

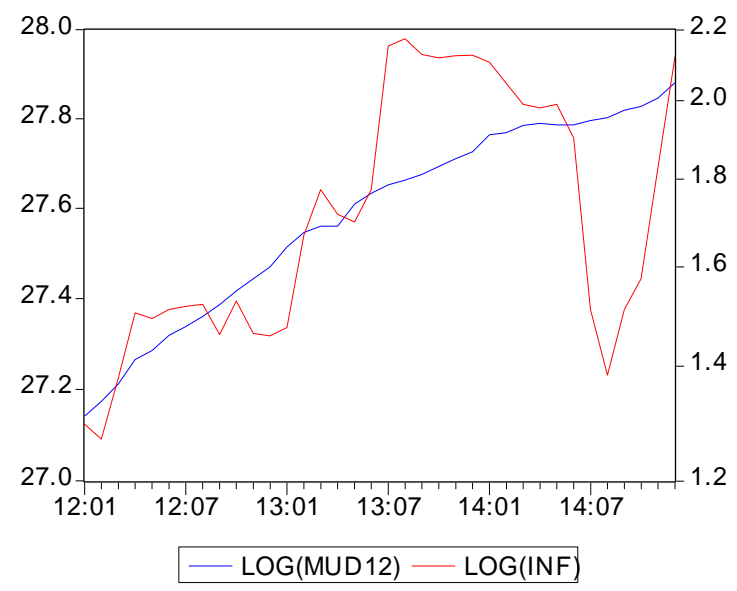

Berdasarkan grafik time series pada gambar di atas terlihat variabel inflasi dan penghimpunan deposito mudharabah mempunyai pola pergerakan yang sama yaitu dari kiri bawah ke kanan atas dengan fluktuasi yang mirip, sehingga diduga kedua variabel ini mempunyai hubungan yang positif. Ketika terjadi inflasi diduga masyarakat melakukan aksi lindung nilai dengan menanamkan dana di BPRS.

3. Grafik Time Series Variabel Deposito Mudharabah dan BI Rate Periode 2012 s.d 2014

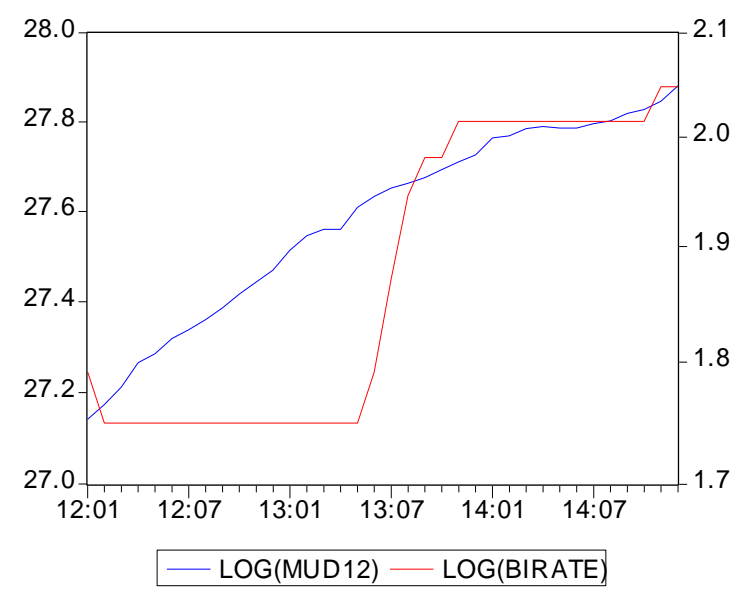

Berdasarkan grafik time series pada gambar di atas terlihat variabel $\mathrm{Bl}$ rate dan penghimpunan deposito mudharabah mempunyai pola pergerakan yang sama yaitu dari kiri bawah ke kanan atas dengan fluktuasi yang mirip, sehingga diduga kedua variabel ini mempunyai hubungan yang positif. 
INKLUSIF Vol 3. No. 2 Desember 2018

4. Grafik Time Series Variabel Deposito Mudharabah dan Nisbah Bagi Hasil Periode 2012 s.d. 2014

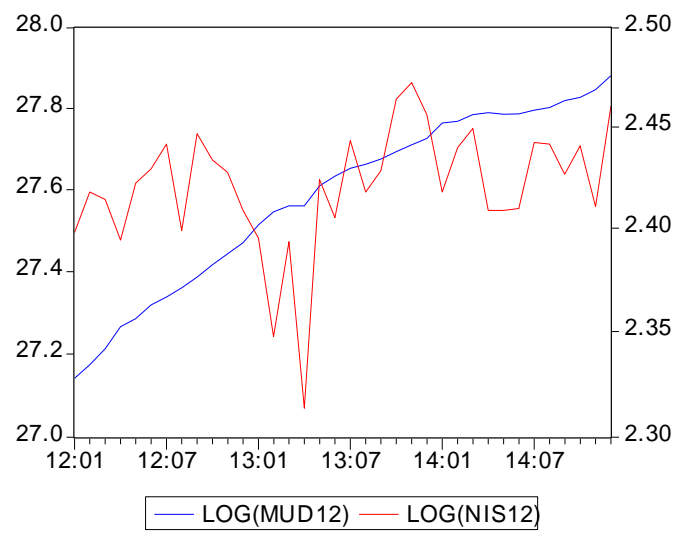

Berdasarkan grafik time series pada gambar di atas terlihat variabel nisbah bagi hasil dan penghimpunan deposito mudharabah mempunyai pola pergerakan yang sama yaitu dari kiri bawah ke kanan atas dengan fluktuasi yang mirip, sehingga diduga kedua variabel ini mempunyai hubungan yang positif.

5. Grafik Time Series Variabel Deposito Mudharabah dan Biaya Promosi Periode 2012 s.d 2014

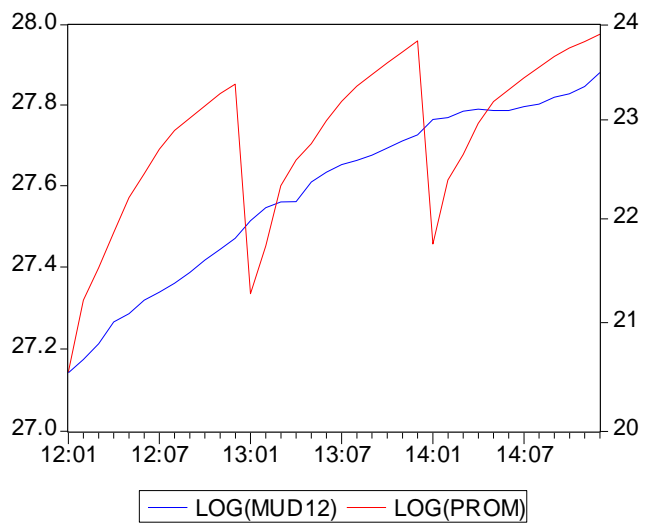

Berdasarkan grafik time series pada gambar di atas terlihat variabel biaya promosi dan penghimpunan deposito mudharabah mempunyai pola pergerakan yang sama yaitu dari kiri bawah ke kanan atas dengan fluktuasi yang mirip, sehingga diduga kedua variabel ini mempunyai hubungan yang positif. 
INKLUSIF Vol 3. No. 2 Desember 2018

6. Grafik Time Series Variabel Deposito Mudharabah dan Jumlah Jaringan Kantor Periode 2012 s.d. 2014

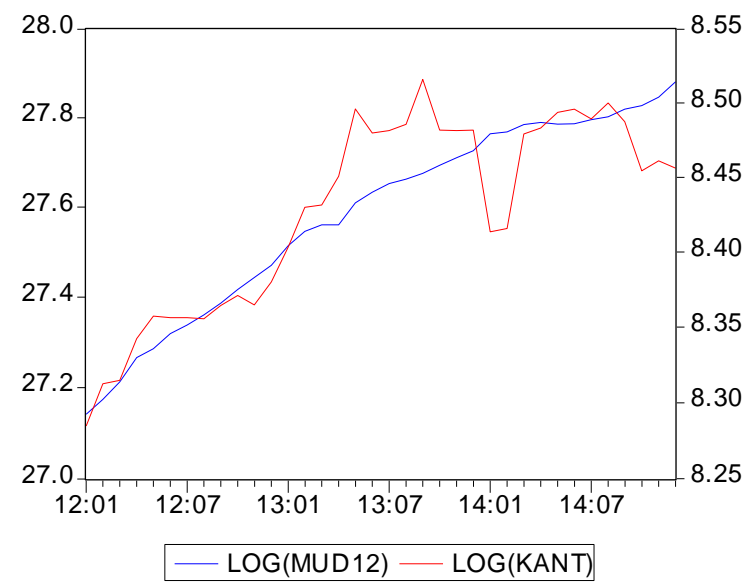

Berdasarkan grafik time series pada gambar di atas terlihat variabel jumlah jaringan kantor dan penghimpunan deposito mudharabah mempunyai pola pergerakan yang sama yaitu dari kiri bawah ke kanan atas dengan fluktuasi yang mirip, sehingga diduga kedua variabel ini mempunyai hubungan yang positif.

7. Grafik Time Series Variabel Deposito Mudharabah dan Jumlah Karyawan Periode 2012 s.d 2014

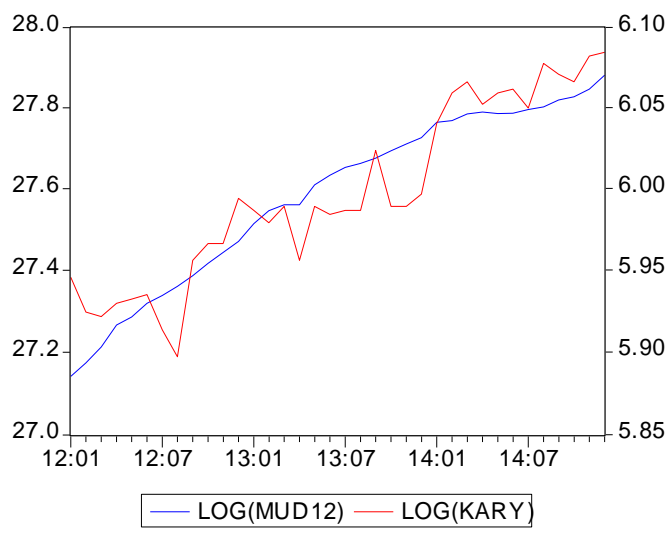

Berdasarkan grafik time series pada gambar di atas terlihat variabel jumlah karyawan dan penghimpunan deposito mudharabah mempunyai pola pergerakan yang sama yaitu dari kiri bawah ke kanan atas dengan fluktuasi yang mirip, sehingga diduga kedua variabel ini mempunyai hubungan yang positif.

Dari hasil penelitian di atas maka dapat artikan bahwa apabila dipandang dari sudut lingkungan bisnis internal khususnya kelembagaan perbankan, maka variabel yang berpengaruh hanya nisbah bagi hasil saja. Lingkungan bisnis eksternal yang berpengaruh hanya $B I$ rate saja sebagai indikator kebijakan pemerintah. Berlakunya koefisien jangka panjang menunjukkan bahwa variabel bebas tidak seketika meningkatkan penghimpunan deposito mudharabah, akan tetapi memerlukan tenggat waktu. 
INKLUSIF Vol 3. No. 2 Desember 2018

\section{Analisis Hasil Penelitian}

Sebagai salah satu hal mendasar dalam bauran pemasaran jasa yaitu place (jumlah jaringan kantor) tidak berpengaruh nyata terhadap penghimpunan deposito mudharabah di BPRS. Padahal Bank Indonesia melalui strategi keuangan inklusif (financial inclusion) sangat menekankan arti penting jaringan kantor karena didasari berbagai sebab yang diidentifikasi menyebabkan masyarakat menjadi unbanked, baik dari sisi supply (penyedia jasa) maupun demand (masyarakat), yaitu karena price barrier (mahal), information barrier (tidak mengetahui), design produk barrier (produk yang cocok) dan channel barrier (sarana yang sesuai). Variabel place ini tentu berhubungan erat dengan people karena penambahan kantor tentu disertai penambahan jumlah karyawan, namum variabel jumlah karyawan dalam penelitian ini tidak berpengaruh nyata. Begitu pula halnya dengan variabel biaya promosi yang tidak berpengaruh nyata.

Edukasi keuangan sebagai salah satu pilar keuangan inklusif dapat dianggap sebagai bagian dari promosi yang bertujuan meningkatkan pengetahuan dan kesadaran masyarakat luas tentang produk-produk dan jasa-jasa keuangan yang ada dalam pasar keuangan formal, aspek perlindungan konsumen dan pemahaman manajemen risiko. Ruang lingkup edukasi keuangan ini meliputi pengetahuan dan kesadaran tentang ragam produk dan jasa keuangan, pengetahuan dan kesadaran tentang risiko terkait dengan produk keuangan, perlindungan nasabah, dan keterampilan dalam mengelola keuangan. ${ }^{18}$

BI Rate sebagai suku bunga kebijakan yang mencerminkan sikap atau stance kebijakan moneter yang ditetapkan oleh Bank Indonesia dan diimplementasikan pada operasi moneter melalui pengelolaan likuiditas di pasar uang untuk mencapai sasaran operasional kebijakan moneter yang dicerminkan pada perkembangan suku bunga Pasar Uang Antar Bank Overnight (PUAB O/N). Pergerakan pada suku bunga PUAB ini diharapkan akan diikuti oleh perkembangan suku bunga deposito dan pada gilirannya suku bunga kredit perbankan. Agar pergerakan suku bunga PUAB o/n tidak terlalu melebar dari anchor-nya (BI Rate), Bank Indonesia berusaha untuk menjaga dan memenuhi kebutuhan likuiditas perbankan secara seimbang sehingga terbentuk suku bunga yang wajar dan stabil melalui pelaksanaan operasi moneter.

Terkait dengan pengaruh BI Rate terhadap deposito mudharabah, model PAM menunjukkan nilai elastisitas jangka panjang yang lebih besar dibandingkan jangka pendeknya. Mekanisme transmisi kebijakan moneter memang bekerja memerlukan waktu (time lag).

\footnotetext{
${ }^{18}$ Bank Indonesia, “Edukasi Keuangan,” 2017.
} 
INKLUSIF Vol 3. No. 2 Desember 2018

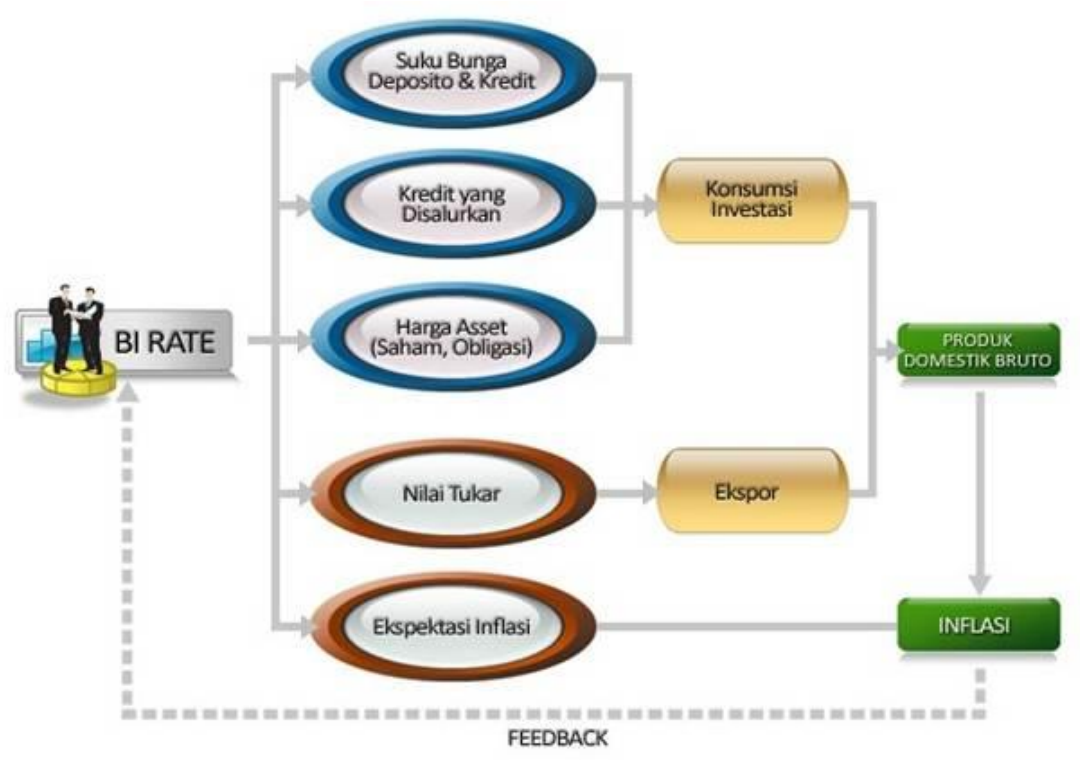

Gambar Mekanisme Transisi Kebijakan Moneter

Dalam kerangka Inflation Targeting Framework, perubahan BI Rate mempengaruhi inflasi melalui berbagai jalur, diantaranya jalur suku bunga, jalur kredit, jalur nilai tukar, jalur harga aset, dan jalur ekspektasi. Pada jalur suku bunga, perubahan BI Rate mempengaruhi suku bunga deposito dan suku bunga kredit perbankan

Dalam rezim suku bunga rendah yang berlanjut hingga awal 2013, persaingan di pasar pendanaan khususnya dalam memperebutkan dana murah seperti giro dan tabungan semakin ketat sehingga perbankan syari'ah yang relatif kecil skala usahanya kembali mengandalkan deposito untuk mengejar target pertumbuhan dana. Namun seiring kenaikan suku bunga dana sebagai respon atas kenaikan $B /$ rate sejak triwulan 2-2013, maka pertumbuhan deposito perbankan syari'ah juga melambat karena sulit menyaingi bank umum konvensional besar yang memiliki struktur pendanaan yang lebih fleksibel yang lebih agresif menaikkan suku bunga. Hal ini tidak lepas dari fleksibilitas bank konvensional dalam penyesuaian suku bunga sesuai perubahan BI rate, jika dibandingkan dengan bank syari'ah khususnya BPRS dimana besar keuntungan untuk nasabah ditentukan berdasarkan kinerja pembiayaan. Kondisi ekonomi riil sangat menentukan fleksibilitas BPRS untuk berdaya saing.

Dari paparan berikut maka dapat disimpulkan bahwa dalam industri perbankan khususnya pasar deposito, kenaikan BI Rate yang direspon positif oleh bank konvensional akan menurunkan daya saing bank syari'ah khususnya BPRS. Karena bersifat kelembagaan eksternal, maka BI rate tidak dapat dikendalikan oleh manajemen BPRS.

Arah hubungan positif antara nisbah bagi hasil dengan penghimpunan deposito mudharabah di BPRS membuktikan bahwa dalam deposito bank syariah yang menggunakan prinsip syariah, dimana besarnya keuntungan (return) yang diberikan kepada deposan tergantung dari besarnya keuntungan yang diperoleh bank dari pembiayaan direspon secara baik oleh nasabah. Nasabah BPRS menentukan keputusan investasinya berdasarkan pertimbangan keuntungan yang berbasis syari'ah. Karena bersifat internal, maka nisbah bagi hasil dapat dikendalikan oleh manajemen BPRS sebagai alat untuk bersaing dengan bank konvensional. 
Dalam jangka pendek koefisien nisbah bagi hasil lebih besar daripada $B I$ Rate, sehingga disimpulkan variabel nisbah bagi hasil lebih berpengaruh daripada BI Rate. Adapun dalam jangka panjang variabel $B I$ Rate lebih berpengaruh daripada nisbah bagi hasil.

\section{PENUTUP}

PDB, inflasi, dan BI rate merupakan faktor ekternal, adapun nisbah bagi hasil, biaya promosi, jumlah kantor, dan jumlah karyawan merupakan faktor internal. Faktor internal memiliki pengaruh terhadap penghimpunan deposito mudharabah pada BPRS di Indonesia. Adapun faktor ekternal yang memiliki pengaruh terhadap penghimpunan deposito mudharabah pada BPRS di Indonesia adalah hanya nisbah bagi hasil.

Terdapat keseimbangan jangka panjang variabel PDB terhadap penghimpunan deposito mudharabah BPRS di Indonesia. Variabel BI Rate dapat menjelaskan keadaan penghimpunan deposito mudharabah BPRS di Indonesia, karena terdapat hubungan determinasi yang sangat kuat. Variabel Inflasi yang berpengaruh nyata secara parsial terhadap penghimpunan deposito mudharabah BPRS di Indonesia baik dalam jangka pendek dan jangka panjang. Variabel Nisbah bagi hasil serempak berpengaruh nyata terhadap penghimpunan deposito mudharabah BPRS di Indonesia. Kinerja BPRS dipengaruhi oleh faktor eksternal yaitu makroekonomi.

Dalam jangka pendek koefisien nisbah bagi hasil lebih besar daripada $B I$ Rate, sehingga dapat disimpulkan variabel nisbah bagi hasil lebih berpengaruh dari pada BI Rate. Dalam jangka panjang variabel $B$ I Rate lebih berpengaruh daripada nisbah bagi hasil.

\section{DAFTAR PUSTAKA}

Alkhafaji, Abbass F. Strategic Management: Formulation, Implementation, and Control In a Dynamic Environme. New York: The Haworth Press, 2003.

Arifin, Veithzal, Arvian, and A Rivai. Islamic Banking: Sebuah Teori, Konsep Dan Aplikasi. Jakarta: PT Bumi Aksara, 2010.

Bank Indonesia. "Edukasi Keuangan," 2017.

Departemen Perbankan Syari'ah. "Laporan Perkembangan Perbankan Syari'ah." Jakarta: Bank Indonesia, 2012.

Hasan, Ali. Marketing Bank Syari'ah. Bogor: Penerbit Ghalia Indonesia, 2010.

Hasibuan, Melayu. Dasar-Dasar Perbankan. jakarta: Bumi Aksara, 2009.

Insukindro, R. Maryatmo, Aliman, S. Y. Kusumastuti, and A. I. Rahutami. Modul Ekonometrika Dasar,

Yogyakarta. Yogyakarta: Bank Indonesia dan Universitas Gadjah Mada, 2004.

Karim, Adiwarman. Ekonomi Makro Islami. Jakarta: PT. Raja Grafindo Persada, 2014.

Loudon, David, Stevens, and Robert Bruce Wrenn. Marketing Management: Text and Cases. New York: Best Business Books, 2005.

Muhammad. Manajemen Bisnis. 2005th ed. Vol. 3. Yogyakarta: UPP AMP YKPN, 2015.

Otoritas Jasa Keuangan. "Laporan Perkembangan Perbankan Syari'ah Bank Indonesia." Jakarta: Departemen Perbankan Syari'ah, 2012.

Santoso, Singgih. Mastering SPSS 18. Jakarta: PT. Elex Media Komputindo, 2010.

Sjahdeini, Remy, and Sutan. Perbankan Syariah. Jakarta: Kencana Prenada Media Group, 2014. 